\title{
Isolation, Characterization and Evaluation of Pink Pigmented Facultative Methylotrophs (PPFMS) Associated with Paddy
}

\author{
N.S. Nysanth ${ }^{1}$, K.S. Meenakumari ${ }^{1}$, Elizabeth K. Syriac ${ }^{2}$ and P. Subha ${ }^{1}$ \\ ${ }^{1}$ Department of Agricultural Microbiology, College of Agriculture, Vellayani-695522, \\ Thiruvananthapuram, Kerala Agricultural University, Kerala, India \\ ${ }^{2}$ Department of Agronomy, College of Agriculture, Vellayani-695522, Thiruvananthapuram, \\ Kerala Agricultural University, Kerala, India
}

*Corresponding author

\section{Keywords \\ Pink pigmented facultative methylotrophs, Phyllosphere, paddy, Kerala}

\section{Article Info}

Accepted:

17 June 2018 Available Online: 10 July 2018

\section{A B S T R A C T}

Methylobacterium spp. are a group of bacteria known as pink-pigmented facultative methylotrophs (PPFMs) capable of growing on single carbon compounds such as formate, formaldehyde, and methanol as well as on a variety of multicarbon compounds having no carbon-carbon bonds. They are distributed ubiquitously in the plant phyllosphere and rhizosphere and have been isolated from many species of plants. Methylotrophs are known to play an important role in increasing crop yield and soil fertility. Methylobacterium is able to produce indole-3-acetic acid (IAA), suggesting that inoculation of PPFM bacteria could increase plant IAA concentrations and promote plant growth. The present programme envisages isolation, characterization and evaluation of Pink Pigmented Facultative Methylotrophs (PPFMs) associated with paddy. As part of the study conducted in the Department of Agricultural Microbiology, College of Agriculture, Vellayani, Thiruvananthapuram, Kerala, during 2015-2017, Pink Pigmented Facultative Methylotrophs (PPFMs) were isolated from the phyllosphere of paddy collected from different agro climatic conditions of Kerala by leaf imprint method using Ammonium Mineral Salt (AMS) agar media supplemented with $0.5 \%$ methanol and cycloheximide. In all, 46 isolates were obtained. The isolates were obtained from different districts of Kerala such as Thiruvananthapuram, Alappuzha and Palakkad including Attappadi hill tract. They were tentatively identified as PPFMs based on the characteristic pink pigmented colonies on AMS agar media with methanol as sole source of carbon and energy. All the 47 PPFM isolates including reference culture were found to produce IAA under in vitro conditions. However, it showed wide variations ranging from 6.74 to $33.35 \mu \mathrm{g} \mathrm{mL}^{-1}$ of culture filtrate. Maximum IAA production of $33.35 \mu \mathrm{g} \mathrm{mL}^{-1}$ of culture was recorded by PPFM35. Paddy seeds [var. Jyothi (Ptb-39)] treated with PPFMs improved seed germination, biomass and seedling vigor index of paddy seedlings. Maximum germination percentage of 100 was recorded in seeds treated with PPFM35. The isolate PPFM22 treated seedlings recorded the highest seedling vigour index of 4756.36 whereas PPFM35 recorded seedling vigour index of 4250.00 over the control (3037.91). The root shoot ratio of seedlings showed significant increase when seeds were treated with PPFM isolates. Maximum root shoot ratio of 0.62 was observed when seeds were treated with PPFM26 and PPFM35 compared to control (0.33). The isolate PPFM35 was adjudged as superior isolate based on indole-3-acetic acid (IAA) production, maximum germination percentage, seedling vigour index and root shoot ratio. This isolate was identified as Methylobacterium populi based on morphological, biochemical and molecular characteristics. 


\section{Introduction}

The living space on the leaf surface, known as the phyllosphere, harbours a wide variety of organisms having beneficial, harmful or neutral effects on the plant. The interaction between such microorganisms and higher plants affect the physiological activities of the plant. Pink pigmented facultative methylotrophs (PPFMs) of the genus Methylobacterium are commonly found in association with plants. It is hypothesized that they potentially dominate the phyllosphere bacterial population. The degree of the plant Methylobacterium association varies from strong, or symbiotic to loose, or epiphytic; a range that also includes the intermediate endophytic association (Lacava et al., 2004). The Methylobacterium spp. is characterized by a distinctive pink pigmentation which is due to the presence of carotenoid pigment (Jyothilaxmi et al., 2012).

PPFMs are aerobic, Gram-negative, methylotrophic rod shaped bacteria, capable of growing on a wide range of multicarbon substrates and also on single carbon compounds such as formate, formaldehyde and methanol as their sole carbon and energy source. It was assumed that significant quantity of methanol is emitted from the plant parts as a by-product of pectin metabolism during cell wall synthesis (McDonald and Fall, 1993; Nemecek- Marshall et al., 1995).Numerous species and strains of Methylobacterium have been isolated from plants (Knief et al., 2010). PPFMs have been isolated from more than 100 species of plants ranging from liverworts and mosses to angiosperms and gymnosperms (Corpe and Basile, 1982). They are isolated on a methanol based mineral medium, Ammonium Mineral Salt (AMS) agar medium supplemented with $0.5 \%$ of methanol and cycloheximide at 100 $\mathrm{mg} \mathrm{L}^{-1}$ (to inhibit fungal growth) by leaf impression method.
Many reports suggest that PPFMs can act as potential agents as plant growth promoters and also help in surviving plants from pathogenic attack (Madhayan et al., 2004). They have been reported to produce plant growth regulators like zeatin and related cytokinins and auxins, which have significant effect on seed germination and seedling growth. Production of gibberellic acid (GA) by Methylobacteria has already been reported (Thangamani, 2005; Radha, 2007; Jones, 2010). Additionally, Methylobacterium have been reported for the production of urease enzyme (Holland and Polacco 1992), vitamin $\mathrm{B}_{12}$ production (Basile et al., 1985), nitrogen fixation and nodule formation (Raja et al., 2006), phosphate solubilization (Jones, 2007), synthesis of siderophores (Simionato et al., 2006) and for the existence and prevalence of ACC deaminase enzyme (Madhaiyan et al., 2006). The first report on the production of IAA in significant amount by methylotrophs was by Ivanova et al. (2001) who detected various indole compounds in the culture liquids of 37 methylotrophic bacteria belonging to different taxa and different strains of Methylobacterium. Auxins produced by theses strains were found to range between 3-100 $\mu \mathrm{g} \mathrm{mL} \mathrm{mL}^{-1}$. Omer et al., (2004) unambiguously confirmed by high performance liquid chromatography in combination with nuclear magnetic resonance chromatography (NMR) that PPFM produced plant hormone IAA. Thangamani and Sundaram (2005) and Radha (2007) have documented production of IAA by PPFM ranging from $3.44 \mu \mathrm{g} \mathrm{mL}^{-1}$ to $25.51 \mu \mathrm{g} \mathrm{mL}^{-1}$ and $9.04 \mu \mathrm{g} \mathrm{mL}$ to $28.15 \mu \mathrm{g} \mathrm{mL}$ respectively. Madhaiyan et al., (2004) observed higher photosynthetic activity in rice cultivar Co-47 that received Methylobacterium and attributed the effect due to enhancement of chlorophyll concentration, maleic acid content and increased number of stomata. Several workers reported growth promotional ability of PPFMs in several crops including 
cotton (Madhaiyan et al., 2005), rice (Senthilkumar, 2003), groundnut (Reddy et al., 2002), tomato (Thangamani and Sundaram, 2005), soybean, blackgram and sugarcane (Madhaiyan et. al., 2005).

Considering the importance of PPFM as plant growth promoting bacteria, an attempt was made to isolate, characterize and to select efficient PPFM strains from paddy based on indole-3-acetic acid (IAA) production and effect on paddy seed germination and seedling growth.

\section{Materials and Methods}

\section{Collection of leaf samples}

The leaf samples of paddy were collected from different agro climatic conditions of Kerala. The samples were brought to the laboratory in sterile polythene bags and stored at $4^{0} \mathrm{C}$.

\section{Isolation of pink pigmented facultative methylotrophs (PPFMs)}

Ammonium Mineral Salts (AMS) medium (Whittenburry et al., 1970) is a selective medium for isolation of methylotrophs. The AMS medium was sterilized by autoclaving at $121^{\circ} \mathrm{C}$ for $15 \mathrm{~min}$ and cooled to $45^{\circ} \mathrm{C}$. Filter sterilized vitamin solution (Colby and Zatman, 1973) along with 0.5 per cent (v/v) methanol was added after sterilization and before pouring media on to petriplates. The $\mathrm{pH}$ of the medium was adjusted to $\mathrm{pH}$ 7.0.

On the solidified AMS agar medium upper and lower surface of leaf samples were placed separately, in such a way as to make impression of it. Then the leaves were lifted away and plates were incubated at $30^{\circ} \mathrm{C}$ for 7 days (Corpe, 1985). Based on characteristic pink pigmentation of colonies they were tentatively identified as PPFMs. The isolate obtained from the commercial product of
Tamil Nadu Agricultural University was taken as reference culture.

\section{Purification of Pink Pigmented Facultative Methylotrophs (PPFMs).}

PPFMs obtained by leaf imprint technique were purified by the streak plate method and well isolated colonies on the plates were preserved on Peptone Glycerol Agar (enrichment medium) slants at $4^{\circ} \mathrm{C}$ in a refrigerator for further use.

Estimation of indole acetic acid production by the different isolates obtained

Indole Acetic Acid was estimated as per the procedure described by Gordon and Weber (1951).

$100 \mathrm{ml}$ of AMS broth supplemented with 0.5 per cent methanol and cycloheximide was prepared in $250 \mathrm{ml}$ flasks. To this medium, 0.1 per cent tryptophan was added. Using sterile technique, the medium was inoculated with one $\mathrm{ml}$ of PPFM inoculum $\left(10^{7} \mathrm{cfu} / \mathrm{ml}\right)$. Flasks were kept for incubation at $30^{\circ} \mathrm{C}$ for 7 days. After incubation, culture was centrifuged at $10000 \mathrm{rpm}$ for 10 minutes. To the $10 \mathrm{ml}$ of culture supernatant $2 \mathrm{ml}$ of the Salkowski reagent was added. Incubated at room temperature for 25 minutes and then read at $\mathrm{OD}_{530}$.

Using the standard curve for IAA, the amount of IAA was calculated.

Effect of isolates of PPFM on paddy seed germination

Seeds of variety Jyothi (Ptb-39) were surface sterilized before treatment with the bacterial suspension. The seeds were first washed with sterile distilled water twice and then treated with $70 \%$ ethanol for $1 \mathrm{~min}$. This was followed by treatment with $2 \%$ sodium hypochlorite solution for 30 seconds. Finally, 
the treated seeds were thoroughly rinsed for more than five times with sterile distilled water. Surface sterilized seeds were soaked overnight in 1 per cent of 7 days old liquid culture $\left(10^{7} \mathrm{cfu} / \mathrm{ml}\right)$ of the respective isolates. After decanting the liquid culture, the dried seeds were placed on filter paper in a petri dish. Plates were incubated at $30^{\circ} \mathrm{C}$ for $72 \mathrm{hrs}$. The untreated seeds were kept as control. The germination percent was calculated after 72 hrs. After taking the number of germinated seeds, percentage seed germination was calculated using the formula,

Seed germination $(\%)=$

Number of germinated seeds

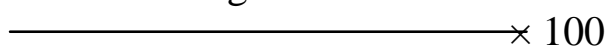

Total number of seeds

\section{Effect of isolates of PPFM on paddy seedling growth}

To calculate the effect of PPFM inoculation on seedling vigor index of paddy, the seeds were surface sterilized with $70 \%$ alcohol and $0.1 \%$ mercuric chloride, which was followed by a series of washings with sterile distilled water. Surface sterilized seeds were soaked overnight in 1 per cent of 7 days old liquid culture $\left(\left(10^{7} \mathrm{cfu} / \mathrm{ml}\right)\right.$ of the respective isolates and sown in plastic pots filled with wetland soil.

The untreated seeds were taken as control. Seedling vigour index was calculated using the formula,

Seedling Vigour Index $=$ Germination Percent $\mathrm{x}$ (Shoot length + Root length) (Baki and Anderson, 1973).

After taking the dry weight of shoot and root (g), Root Shoot ratio was calculated using the formula,

Root Shoot Ratio =

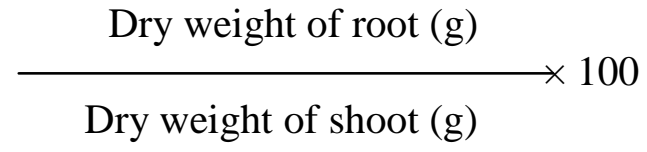

\section{Morphological, biochemical and molecular characterization of isolates of PPFM}

Morphological tests viz., cell shape, gram reaction and motility were carried out to characterize the tentatively identified PPFM isolate. Biochemical characterization of selected bacterial isolate were done by performing various biochemical tests and carbohydrate utilization tests by using readymade Himedia ${ }^{\odot}$ kits $\left(\mathrm{HiCarbo}^{\mathrm{TM}}\right.$, Part A, Band C, Hi25 ${ }^{\mathrm{TM}}$ Enterobacteriaceae). Colour change observed on the biochemical amended media of the kit after spot inoculating culture suspensions of selected isolates followed by incubation for $72 \mathrm{~h}$ indicated the reaction with respect to different biochemicals or carbohydrates as positive or negative. The results of biochemical tests were utilized to arrive at a tentative genus level identification of isolate. Bergey's manual of determinative of bacteriology was used as a reference to identify the isolate. Molecular characterization of selected isolate was done by $16 \mathrm{~S}$ rRNA cataloging using universal primers.

\section{Results and Discussion}

The pink pigmented facultative methylobacteria (PPFM) were isolated from the phyllosphere of paddy, collected from different locations of Kerala. Isolations were made following leaf imprint method using Ammonium Mineral Salt (AMS) agar media supplemented with $0.5 \%$ methanol and cycloheximide (Lindstrom and Chistoserdova, 2002). Forty six isolates were obtained from different locations and allotted code numbers for each of the isolate. They were tentatively identified as PPFMs based on the characteristic pink pigmented colonies on 
AMS agar media with methanol as sole source of carbon and energy (Plate 1and Plate 2). The isolate obtained from the commercial product of Tamil Nadu Agricultural University was taken as reference culture.

The first report on the production of IAA in significant amount by methylotrophs was by Ivanova et al. (2001) who detected various indole compounds in the culture liquids of 37 methylotrophic bacteria belonging to different taxa and different strains of Methylobacterium. Auxins produced by these strains were found to range between 3-100 $\mu \mathrm{g}$ $\mathrm{mL}^{-1}$. Omer et al., (2004) unambiguously confirmed by high performance liquid chromatography in combination with nuclear magnetic resonance chromatography (NMR) that PPFM produced plant hormone IAA. Thangamani and Sundaram (2005) and Radha (2007) have documented production of IAA by PPFM ranging from $3.44 \mu \mathrm{g} \mathrm{mL}^{-1}$ to 25.51 $\mu \mathrm{g} \mathrm{mL}^{-1}$ and $9.04 \mu \mathrm{g} \mathrm{mL}^{-1}$ to $28.15 \mu \mathrm{g} \mathrm{mL}^{-1}$ respectively. Methylobacterium is able to produce IAA, suggesting that inoculation of these bacteria could increase plant IAA concentrations and promote plant growth (Lee et al., 2006). The presence of IAA was reported in supernatants of PPFM cultures (Omer et al., 2004). There are numerous reports available on indole-3-acetic acid (IAA) production by PPFMs (Omer et al., 2004; Anitha, 2010). In the present investigation, all the 47 PPFM isolates were found to produce IAA under in vitro conditions. However, it showed wide variations ranging from 6.74 to $33.35 \mu \mathrm{g} \mathrm{mL} \mathrm{m}^{-1}$ of culture filtrate. Maximum IAA production of $33.35 \mu \mathrm{g} \mathrm{mL} \mathrm{m}^{-1}$ of culture was recorded by PPFM35. The reference culture produced $18.01 \mu \mathrm{g} \mathrm{mL}^{-1}$ of IAA (Table $1)$.

PPFMs have been reported to influence seed germination and seedling growth by producing plant growth regulators like zeatin and related cytokinins and auxins. Seeds treated with the methylotrophic strains improved seed germination, seedling vigor index (SVI) and biomass of rice seedlings. The methylotrophic population in the treated seedlings increased in the vegetative stages when compared to seeding stages. Treated seedlings showed a higher accumulation of plant hormones viz trans-zeatin riboside, isopentenyladenosine, and indole-3-acetic acid than untreated seedlings (Lee et al., 2006). Based on these findings, effect of PPFM isolates on paddy seed germination and seedling growth was tested and the results revealed that the germination percentage of inoculated seeds showed a significant increase compared to uninoculated control. Maximum germination percentage of 100 was recorded in seeds treated with PPFM35. This treatment was found to be significantly superior to the uninoculated control which recorded a germination percentage of 86 per cent (Table 2).

The present investigation conclusively proved that, PPFM inoculation in paddy seeds had significant effect on biomass and seedling vigor index (Plate 3). Observations on shoot length and root length of PPFM isolates inoculated seeds, after 14 days of sowing showed a significant increase compared to uninoculated control. Inoculation with PPFM6 recorded the maximum shoot length of 26.38 $\mathrm{cm}$ and was found to be significantly superior to the uninoculated control which recorded a shoot length of $17.84 \mathrm{~cm}$. The reference culture treated seedlings recorded a shoot length of $23.03 \mathrm{~cm}$. Maximum root length of $24.20 \mathrm{~cm}$ was obtained in seeds treated with PPFM22 and this treatment was significantly superior to the uninoculated control and reference strain which recorded a root length of 17.50 and $18.90 \mathrm{~cm}$ respectively. Paddy seeds treated with PPFM22 recorded the highest seedling vigour index of 4756.36, whereas, PPFM35 recorded seedling vigour index of 4250.00 and this was significantly 
superior compared to the control which recorded a vigour index of 3037.91. The reference culture recorded a seedling vigour index of 3943.45 (Table 3)

Significant increase in seedling shoot fresh weight, root fresh weight, shoot dry weight, root dry weight and root shoot ratio compared to control was observed when seeds were treated with PPFM isolates. In the present investigation, PPFM26 and PPFM35 strains gave the best performance of seedling root shoot ratio and increased significantly with value of 0.62 . These treatments showed 87.88 per cent increase in root shoot ratio over uninoculated control (Table 4 and 5).

The isolate PPFM35 was adjudged as superior isolate based on indole-3-acetic acid (IAA) production, maximum germination percentage, seedling vigour index and root shoot ratio of paddy seedlings. This selected isolate was characterized based on morphological, biochemical and molecular characteristics.

Microscopic studies revealed that the PPFM isolates were rod shaped, motile, gram negative and produced poly $\beta$-hydroxy butyrate granules (Green and Bousifield, 1982). In the present investigation, the superior isolate selected was subjected to morphological characterization. The results revealed that the isolate was rod shaped, stained Gram negative and exhibited motility (Plate 4). The expression of pink pigmentation with varied level of intensity in PPFM indicates the presence of carotenoids (Fasim, 2003) which is known to protect these bacteria from intense light and UV radiation (Liu et al., 1993). In the present study, medium pink coloured colonies of PPFM35 were observed after one week of incubation (Table 6).

All isolates were aerobes producing catalase and oxidase as already demonstrated by Bellin and Spain (1976) and positive for urease test and indole production (Thangamani, 2005). However, hydrolysis of casein, starch, cellulose degradation, MR and VP test and nitrate reduction test was not recorded in any of the isolates.

In the present investigation, for further characterization, the isolate PPFM35 was subjected to a series of biochemical tests (Table 7).

The methylotrophic bacteria having capability to grow on different single carbon compounds as sole source of carbon and energy, can also grow on wide range of multi carbon growth substrates making them facultatively methylotrophic. The selected isolate was tested for the utilization of the 29 different carbon compounds. Using the results of various biochemical tests, a tentative genus level identification was done. Bergey's manual of determinative of bacteriology was used as a reference to identify the isolate and the isolate PPFM35 was identified to belong to genus Methylobacterium. The results are presented in Table 8.

The present investigation demonstrated that it is possible to distinguish and classify the methylotrophic bacteria using $16 \mathrm{~S}$ rRNA sequence analysis. Our results also indicated that phylogenetic relationships based on $16 \mathrm{~S}$ rRNA sequences reflect the classical taxonomic classification systems based on phenotypic characteristics for methylotrophs. Thus, $\quad 16 \mathrm{~S}$ rRNA sequence analysis could be a useful tool for detailed classification of methylotrophs. 16S rRNA gene phylogenetic analysis performed clearly showed the position of the isolate within the genus Methylobacterium. The 16S rRNA gene sequencing analysis showed $100 \%$ homology with that of Methylobacterium populi in the existing database of National Center of Bioinformatics. 
Table.1 Indole-acetic acid (IAA) production by the PPFM isolates

\begin{tabular}{|c|c|c|}
\hline Sl. No. & $\begin{array}{l}\text { Isolate } \\
\text { code No. }\end{array}$ & $\begin{array}{c}\text { IAA } \\
\left(\mu \mathrm{g} \mathbf{m L}^{-1}\right)^{*}\end{array}$ \\
\hline 1 & PPFM1 & 7.12 \\
\hline 2 & PPFM2 & 19.52 \\
\hline 3 & PPFM3 & 25.67 \\
\hline 4 & PPFM4 & 19.82 \\
\hline 5 & PPFM5 & 11.09 \\
\hline 6 & PPFM6 & 15.77 \\
\hline 7 & PPFM7 & 19.44 \\
\hline 8 & PPFM8 & 16.24 \\
\hline 9 & PPFM9 & 17.40 \\
\hline 10 & PPFM10 & 9.33 \\
\hline 11 & PPFM11 & 22.60 \\
\hline 12 & PPFM12 & 8.09 \\
\hline 13 & PPFM13 & 7.28 \\
\hline 14 & PPFM14 & 8.26 \\
\hline 15 & PPFM15 & 10.47 \\
\hline 16 & PPFM16 & 9.78 \\
\hline 17 & PPFM17 & 9.55 \\
\hline 18 & PPFM18 & 6.74 \\
\hline 19 & PPFM19 & 19.67 \\
\hline 20 & PPFM20 & 29.19 \\
\hline 21 & PPFM21 & 22.74 \\
\hline 22 & PPFM22 & 16.55 \\
\hline 23 & PPFM23 & 9.92 \\
\hline 24 & PPFM24 & 22.88 \\
\hline 25 & PPFM25 & 19.19 \\
\hline 26 & PPFM26 & 24.73 \\
\hline
\end{tabular}


Int.J.Curr.Microbiol.App.Sci (2018) 7(7): 2187-2210

\begin{tabular}{|c|c|c|}
\hline 27 & PPFM27 & 8.97 \\
\hline 28 & PPFM28 & 10.64 \\
\hline 29 & PPFM29 & 6.89 \\
\hline 30 & PPFM30 & 25.16 \\
\hline 31 & PPFM31 & 9.61 \\
\hline 32 & PPFM32 & 10.98 \\
\hline 33 & PPFM33 & 7.30 \\
\hline 34 & PPFM34 & 11.27 \\
\hline 35 & PPFM35 & 33.35 \\
\hline 36 & PPFM36 & 18.39 \\
\hline 37 & PPFM37 & 29.72 \\
\hline 38 & PPFM38 & 22.43 \\
\hline 39 & PPFM39 & 19.74 \\
\hline 40 & PPFM40 & 7.74 \\
\hline 41 & PPFM41 & 13.01 \\
\hline 42 & PPFM42 & 20.25 \\
\hline 43 & PPFM43 & 13.23 \\
\hline 44 & PPFM44 & 8.58 \\
\hline 45 & PPFM45 & 12.93 \\
\hline 46 & PPFM46 & 15.79 \\
\hline 47 & $\begin{array}{l}\text { PPFM47 } \\
\text { (Reference } \\
\text { strain) }\end{array}$ & 18.01 \\
\hline & $\mathrm{CD}(0.05)$ & 6.14 \\
\hline & $\operatorname{SEm}( \pm)$ & 2.15 \\
\hline
\end{tabular}

* Mean of 2 independent replications 
Table.2 Effect of PPFM isolates on paddy seed germination

\begin{tabular}{|c|c|c|}
\hline Sl. No. & Isolate code No. & $\begin{array}{c}\text { Seed germination* } \\
(\%)\end{array}$ \\
\hline 1 & PPFM1 & 93.00 \\
\hline 2 & PPFM2 & 93.00 \\
\hline 3 & PPFM3 & 94.00 \\
\hline 4 & PPFM4 & 87.67 \\
\hline 5 & PPFM5 & 84.33 \\
\hline 6 & PPFM6 & 89.67 \\
\hline 7 & PPFM7 & 89.67 \\
\hline 8 & PPFM8 & 96.00 \\
\hline 9 & PPFM9 & 95.00 \\
\hline 10 & PPFM10 & 96.00 \\
\hline 11 & PPFM11 & 98.00 \\
\hline 12 & PPFM12 & 93.00 \\
\hline 13 & PPFM13 & 92.33 \\
\hline 14 & PPFM14 & 90.67 \\
\hline 15 & PPFM15 & 87.67 \\
\hline 16 & PPFM16 & 94.00 \\
\hline 17 & PPFM17 & 75.33 \\
\hline 18 & PPFM18 & 90.67 \\
\hline 19 & PPFM19 & 95.00 \\
\hline 20 & PPFM20 & 79.33 \\
\hline 21 & PPFM21 & 86.33 \\
\hline 22 & PPFM22 & 96.00 \\
\hline 23 & PPFM23 & 79.67 \\
\hline 24 & PPFM24 & 95.00 \\
\hline 25 & PPFM25 & 93.00 \\
\hline 26 & PPFM26 & 94.00 \\
\hline
\end{tabular}


Int.J.Curr.Microbiol.App.Sci (2018) 7(7): 2187-2210

\begin{tabular}{|c|c|c|}
\hline 27 & PPFM27 & 98.00 \\
\hline 28 & PPFM28 & 84.67 \\
\hline 29 & PPFM29 & 97.00 \\
\hline 30 & PPFM30 & 98.00 \\
\hline 31 & PPFM31 & 95.00 \\
\hline 32 & PPFM32 & 93.00 \\
\hline 33 & PPFM33 & 91.00 \\
\hline 34 & PPFM34 & 94.00 \\
\hline 35 & PPFM35 & 100.00 \\
\hline 36 & PPFM36 & 92.00 \\
\hline 37 & PPFM37 & 92.00 \\
\hline 38 & PPFM38 & 93.00 \\
\hline 39 & PPFM39 & 77.67 \\
\hline 40 & PPFM40 & 97.67 \\
\hline 41 & PPFM41 & 90.67 \\
\hline 42 & PPFM42 & 96.00 \\
\hline 43 & PPFM43 & 86.00 \\
\hline 44 & PPFM44 & 90.00 \\
\hline 45 & PPFM45 & 84.67 \\
\hline 46 & PPFM46 & 88.00 \\
\hline 47 & $\begin{array}{c}\text { PPFM47 } \\
\text { (Reference strain) }\end{array}$ & 94.00 \\
\hline \multirow[t]{3}{*}{48} & Control & 86.00 \\
\hline & CD (0.05) & 6.92 \\
\hline & $\operatorname{SEm}( \pm)$ & 2.46 \\
\hline
\end{tabular}

*Mean of 3 independent replications 
Table.3 Effect of PPFM isolates on shoot length, root length and seedling vigour index of paddy seedlings

\begin{tabular}{|c|c|c|c|c|}
\hline $\begin{array}{l}\text { Sl. } \\
\text { No. }\end{array}$ & $\begin{array}{c}\text { Isolate } \\
\text { code No. }\end{array}$ & $\begin{array}{c}\text { Shoot length }(\mathrm{cm}) / \\
\text { seedling* }\end{array}$ & $\begin{array}{c}\text { Root length }(\mathrm{cm}) / \\
\text { seedling* }\end{array}$ & Seedling Vigour Index \\
\hline 1 & PPFM1 & 19.58 & 17.93 & $3,489.06$ \\
\hline 2 & PPFM2 & 24.62 & 19.70 & $4,121.48$ \\
\hline 3 & PPFM3 & 25.02 & 17.90 & $4,039.46$ \\
\hline 4 & PPFM4 & 25.00 & 22.40 & $4,155.06$ \\
\hline 5 & PPFM5 & 25.25 & 18.80 & $3,716.88$ \\
\hline 6 & PPFM6 & 26.38 & 17.57 & $3,939.10$ \\
\hline 7 & PPFM7 & 20.03 & 17.70 & $3,380.53$ \\
\hline 8 & PPFM8 & 25.72 & 20.17 & $4,402.82$ \\
\hline 9 & PPFM9 & 23.38 & 24.10 & $4,515.58$ \\
\hline 10 & PPFM10 & 19.77 & 19.67 & $3,784.00$ \\
\hline 11 & PPFM11 & 19.75 & 22.80 & $4,173.17$ \\
\hline 12 & PPFM12 & 21.25 & 22.60 & $4,073.94$ \\
\hline 13 & PPFM13 & 21.25 & 18.57 & $3,656.82$ \\
\hline 14 & PPFM14 & 24.40 & 18.40 & $3,885.80$ \\
\hline 15 & PPFM15 & 23.80 & 21.50 & $3,963.71$ \\
\hline 16 & PPFM16 & 21.95 & 20.87 & $4,021.87$ \\
\hline 17 & PPFM17 & 20.12 & 17.97 & $2,849.70$ \\
\hline 18 & PPFM18 & 23.17 & 17.70 & $3,707.40$ \\
\hline 19 & PPFM19 & 23.50 & 18.87 & $4,020.85$ \\
\hline 20 & PPFM20 & 23.61 & 20.03 & $3,465.24$ \\
\hline 21 & PPFM21 & 24.82 & 21.30 & $3,978.15$ \\
\hline 22 & PPFM22 & 25.38 & 24.20 & $4,756.36$ \\
\hline 23 & PPFM23 & 24.07 & 17.93 & $3,345.03$ \\
\hline 24 & PPFM24 & 25.38 & 20.03 & $4,313.27$ \\
\hline 25 & PPFM25 & 22.60 & 19.23 & $3,889.83$ \\
\hline 26 & PPFM26 & 24.75 & 18.70 & $4,090.04$ \\
\hline
\end{tabular}


Int.J.Curr.Microbiol.App.Sci (2018) 7(7): 2187-2210

\begin{tabular}{|c|c|c|c|c|}
\hline 27 & PPFM27 & 22.08 & 15.87 & $3,719.78$ \\
\hline 28 & PPFM28 & 23.50 & 18.97 & $3,570.58$ \\
\hline 29 & PPFM29 & 20.55 & 19.73 & $3,904.60$ \\
\hline 30 & PPFM30 & 23.60 & 20.13 & $4,285.96$ \\
\hline 31 & PPFM31 & 25.85 & 14.20 & $3,813.18$ \\
\hline 32 & PPFM32 & 23.68 & 18.27 & $3,900.67$ \\
\hline 33 & PPFM33 & 21.37 & 18.23 & $3,604.07$ \\
\hline 34 & PPFM34 & 24.97 & 18.17 & $4,054.37$ \\
\hline 35 & PPFM35 & 23.37 & 19.13 & $4,250.00$ \\
\hline 36 & PPFM36 & 24.33 & 19.60 & $4,037.78$ \\
\hline 37 & PPFM37 & 23.20 & 18.97 & $3,877.02$ \\
\hline 38 & PPFM38 & 22.35 & 19.70 & $3,912.22$ \\
\hline 39 & PPFM39 & 22.02 & 19.60 & $3,221.33$ \\
\hline 40 & PPFM40 & 21.55 & 17.57 & $3,817.84$ \\
\hline 41 & PPFM41 & 23.65 & 15.47 & $3,545.07$ \\
\hline 42 & PPFM42 & 24.34 & 21.33 & $4,385.67$ \\
\hline 43 & PPFM43 & 19.17 & 22.00 & $3,537.80$ \\
\hline 44 & PPFM44 & 20.95 & 21.17 & $3,786.82$ \\
\hline 45 & PPFM45 & 23.67 & 21.97 & $3,867.93$ \\
\hline 46 & PPFM46 & 26.25 & 19.07 & $3,986.13$ \\
\hline 47 & $\begin{array}{l}\text { PPFM47 } \\
\text { (Reference } \\
\text { strain) }\end{array}$ & 23.03 & 18.90 & $3,943.45$ \\
\hline \multirow[t]{3}{*}{48} & Control & 17.84 & 17.50 & $3,037.91$ \\
\hline & $\mathrm{CD}(0.05)$ & 2.91 & 1.34 & 365.25 \\
\hline & $\operatorname{SEm}( \pm)$ & 1.03 & 0.48 & 129.91 \\
\hline
\end{tabular}

*Mean of 3 replications 
Table.4 Effect of PPFM isolates on shoot and root fresh weight of paddy seedlings

\begin{tabular}{|c|c|c|c|}
\hline $\begin{array}{l}\text { Sl. } \\
\text { No. }\end{array}$ & $\begin{array}{l}\text { Isolate } \\
\text { code No. }\end{array}$ & $\begin{array}{c}\begin{array}{c}\text { Shoot fresh weight } \\
\text { seedling* }\end{array} \\
(\mathrm{g}) /\end{array}$ & $\begin{array}{l}\text { Root fresh weight } \\
\text { (g)/ seedling* }\end{array}$ \\
\hline 1 & PPFM1 & 0.51 & 0.25 \\
\hline 2 & PPFM2 & 0.45 & 0.21 \\
\hline 3 & PPFM3 & 0.54 & 0.30 \\
\hline 4 & PPFM4 & 0.54 & 0.28 \\
\hline 5 & PPFM5 & 0.53 & 0.26 \\
\hline 6 & PPFM6 & 0.65 & 0.33 \\
\hline 7 & PPFM7 & 0.57 & 0.28 \\
\hline 8 & PPFM8 & 0.67 & 0.30 \\
\hline 9 & PPFM9 & 0.63 & 0.29 \\
\hline 10 & PPFM10 & 0.56 & 0.25 \\
\hline 11 & PPFM11 & 0.54 & 0.25 \\
\hline 12 & PPFM12 & 0.52 & 0.26 \\
\hline 13 & PPFM13 & 0.54 & 0.23 \\
\hline 14 & PPFM14 & 0.62 & 0.27 \\
\hline 15 & PPFM15 & 0.60 & 0.27 \\
\hline 16 & PPFM16 & 0.60 & 0.35 \\
\hline 17 & PPFM17 & 0.57 & 0.22 \\
\hline 18 & PPFM18 & 0.55 & 0.25 \\
\hline 19 & PPFM19 & 0.58 & 0.30 \\
\hline 20 & PPFM20 & 0.60 & 0.29 \\
\hline 21 & PPFM21 & 0.61 & 0.30 \\
\hline 22 & PPFM22 & 0.58 & 0.29 \\
\hline 23 & PPFM23 & 0.55 & 0.24 \\
\hline 24 & PPFM24 & 0.66 & 0.30 \\
\hline 25 & PPFM25 & 0.57 & 0.31 \\
\hline 26 & PPFM26 & 0.57 & 0.33 \\
\hline 27 & PPFM27 & 0.56 & 0.27 \\
\hline
\end{tabular}


Int.J.Curr.Microbiol.App.Sci (2018) 7(7): 2187-2210

\begin{tabular}{|c|c|c|c|}
\hline 28 & PPFM28 & 0.52 & 0.25 \\
\hline 29 & PPFM29 & 0.55 & 0.29 \\
\hline 30 & PPFM30 & 0.60 & 0.31 \\
\hline 31 & PPFM31 & 0.50 & 0.24 \\
\hline 32 & PPFM32 & 0.57 & 0.28 \\
\hline 33 & PPFM33 & 0.65 & 0.30 \\
\hline 34 & PPFM34 & 0.54 & 0.27 \\
\hline 35 & PPFM35 & 0.58 & 0.34 \\
\hline 36 & PPFM36 & 0.54 & 0.24 \\
\hline 37 & PPFM37 & 0.57 & 0.30 \\
\hline 38 & PPFM38 & 0.46 & 0.23 \\
\hline 39 & PPFM39 & 0.61 & 0.29 \\
\hline 40 & PPFM40 & 0.59 & 0.25 \\
\hline 41 & PPFM41 & 0.61 & 0.27 \\
\hline 42 & PPFM42 & 0.67 & 0.32 \\
\hline 43 & PPFM43 & 0.49 & 0.23 \\
\hline 44 & PPFM44 & 0.42 & 0.26 \\
\hline 45 & PPFM45 & 0.65 & 0.34 \\
\hline 46 & PPFM46 & 0.56 & 0.26 \\
\hline 47 & $\begin{array}{c}\text { PPFM47 } \\
\text { (Reference strain) }\end{array}$ & 0.54 & 0.28 \\
\hline \multirow[t]{3}{*}{48} & Control & 0.57 & 0.24 \\
\hline & $\mathrm{CD}(0.05)$ & 0.096 & 0.050 \\
\hline & $\operatorname{SEm}( \pm)$ & 0.03 & 0.02 \\
\hline
\end{tabular}

*Mean of 3 replications 
Table.5 Effect of PPFM isolates on shoot dry weight, root dry weight and root shoot ratio of paddy seedlings

\begin{tabular}{|c|c|c|c|c|}
\hline $\begin{array}{l}\text { Sl. } \\
\text { No. }\end{array}$ & $\begin{array}{c}\text { Isolate } \\
\text { code No. }\end{array}$ & $\begin{array}{l}\text { Shoot dry weight } \\
\text { (g)/ seedling* }\end{array}$ & $\begin{array}{l}\text { Root dry weight } \\
\text { (g)/ seedling* }\end{array}$ & RS Ratio \\
\hline 1 & PPFM1 & 0.21 & 0.09 & 0.41 \\
\hline 2 & PPFM2 & 0.16 & 0.05 & 0.32 \\
\hline 3 & PPFM3 & 0.24 & 0.14 & 0.58 \\
\hline 4 & PPFM4 & 0.28 & 0.12 & 0.43 \\
\hline 5 & PPFM5 & 0.23 & 0.10 & 0.42 \\
\hline 6 & PPFM6 & 0.35 & 0.17 & 0.48 \\
\hline 7 & PPFM7 & 0.26 & 0.12 & 0.45 \\
\hline 8 & PPFM8 & 0.34 & 0.14 & 0.43 \\
\hline 9 & PPFM9 & 0.33 & 0.13 & 0.39 \\
\hline 10 & PPFM10 & 0.26 & 0.09 & 0.36 \\
\hline 11 & PPFM11 & 0.24 & 0.09 & 0.36 \\
\hline 12 & PPFM12 & 0.22 & 0.10 & 0.45 \\
\hline 13 & PPFM13 & 0.24 & 0.07 & 0.29 \\
\hline 14 & PPFM14 & 0.32 & 0.11 & 0.35 \\
\hline 15 & PPFM15 & 0.30 & 0.11 & 0.35 \\
\hline 16 & PPFM16 & 0.33 & 0.19 & 0.57 \\
\hline 17 & PPFM17 & 0.27 & 0.06 & 0.24 \\
\hline 18 & PPFM18 & 0.25 & 0.09 & 0.36 \\
\hline 19 & PPFM19 & 0.28 & 0.14 & 0.51 \\
\hline 20 & PPFM20 & 0.30 & 0.13 & 0.45 \\
\hline 21 & PPFM21 & 0.27 & 0.14 & 0.54 \\
\hline 22 & PPFM22 & 0.28 & 0.13 & 0.46 \\
\hline 23 & PPFM23 & 0.25 & 0.08 & 0.31 \\
\hline 24 & PPFM24 & 0.36 & 0.14 & 0.40 \\
\hline 25 & PPFM25 & 0.27 & 0.15 & 0.54 \\
\hline 26 & PPFM26 & 0.27 & 0.17 & 0.62 \\
\hline 27 & PPFM27 & 0.26 & 0.11 & 0.43 \\
\hline
\end{tabular}


Int.J.Curr.Microbiol.App.Sci (2018) 7(7): 2187-2210

\begin{tabular}{|c|c|c|c|c|}
\hline 28 & PPFM28 & 0.22 & 0.09 & 0.40 \\
\hline 29 & PPFM29 & 0.25 & 0.13 & 0.54 \\
\hline 30 & PPFM30 & 0.30 & 0.15 & 0.49 \\
\hline 31 & PPFM31 & 0.20 & 0.08 & 0.41 \\
\hline 32 & PPFM32 & 0.27 & 0.12 & 0.47 \\
\hline 33 & PPFM33 & 0.28 & 0.14 & 0.48 \\
\hline 34 & PPFM34 & 0.24 & 0.11 & 0.47 \\
\hline 35 & PPFM35 & 0.28 & 0.18 & 0.62 \\
\hline 36 & PPFM36 & 0.24 & 0.08 & 0.35 \\
\hline 37 & PPFM37 & 0.27 & 0.14 & 0.53 \\
\hline 38 & PPFM38 & 0.16 & 0.07 & 0.43 \\
\hline 39 & PPFM39 & 0.31 & 0.13 & 0.43 \\
\hline 40 & PPFM40 & 0.29 & 0.09 & 0.33 \\
\hline 41 & PPFM41 & 0.31 & 0.11 & 0.34 \\
\hline 42 & PPFM42 & 0.37 & 0.20 & 0.52 \\
\hline 43 & PPFM43 & 0.19 & 0.07 & 0.38 \\
\hline 44 & PPFM44 & 0.26 & 0.10 & 0.39 \\
\hline 45 & PPFM45 & 0.35 & 0.17 & 0.48 \\
\hline 46 & PPFM46 & 0.26 & 0.10 & 0.37 \\
\hline 47 & PPFM47 (Reference strain) & 0.24 & 0.12 & 0.48 \\
\hline \multirow[t]{3}{*}{48} & Control & 0.27 & 0.09 & 0.33 \\
\hline & $\mathrm{CD}(0.05)$ & 0.078 & 0.039 & 0.054 \\
\hline & $\operatorname{SEm}( \pm)$ & 0.03 & 0.01 & 0.02 \\
\hline
\end{tabular}

*Mean of 3 replications 
Table.6 Morphological characterization of selected PPFM isolate

\begin{tabular}{|c|c|c|c|c|c|}
\hline $\begin{array}{c}\text { SI. } \\
\text { No. }\end{array}$ & $\begin{array}{c}\text { Isolate code } \\
\text { No. }\end{array}$ & Cell shape & Motility & $\begin{array}{c}\text { Gram } \\
\text { reaction }\end{array}$ & Pigmentation \\
\hline $\mathbf{1}$ & PPFM35 & Rod & Positive & Negative & Medium pink \\
\hline
\end{tabular}

Table.7 Biochemical characterization of selected PPFM isolate

\begin{tabular}{|c|c|c|}
\hline Sl. No & Biochemical Tests & PPFM35 \\
\hline $\mathbf{1}$ & Citrate utilization & Positive \\
\hline $\mathbf{2}$ & Lysine utilization & Positive \\
\hline $\mathbf{3}$ & Ornithine utilization & Positive \\
\hline $\mathbf{4}$ & Urease & Positive \\
\hline $\mathbf{5}$ & Phenylalanine deamination & Negative \\
\hline $\mathbf{6}$ & Hos production & Negative \\
\hline $\mathbf{7}$ & Nitrate reduction & Negative \\
\hline $\mathbf{8}$ & Catalase & Positive \\
\hline $\mathbf{9}$ & Arginine lyase & Negative \\
\hline $\mathbf{1 0}$ & Malonate utilization & Positive \\
\hline $\mathbf{1 1}$ & VogesProskauer & Negative \\
\hline $\mathbf{1 2}$ & Indole & Positive \\
\hline $\mathbf{1 3}$ & Oxidase & Positive \\
\hline
\end{tabular}


Table.8 Utilization of different carbon substrates by selected PPFM isolate

\begin{tabular}{|c|c|c|}
\hline Sl. No & Carbon Substrate & PPFM35 \\
\hline 1 & D- Glucose & Positive \\
\hline 2 & D- Fucose & Negative \\
\hline 3 & D- Xylose & Negative \\
\hline 4 & L- Arabinose & Negative \\
\hline 5 & D- Fructose & Positive \\
\hline 6 & L- Aspartate/ L- Glutamate & Negative \\
\hline 7 & Sebacate & Negative \\
\hline 8 & Acetate & Positive \\
\hline 9 & Betaine & Positive \\
\hline 10 & Tartarate & Positive \\
\hline 11 & Ethanol & Positive \\
\hline 12 & Methylamine & Negative \\
\hline 13 & Dimethylamine & Positive \\
\hline 14 & Formaldehyde & Positive \\
\hline 15 & Glycerol & Positive \\
\hline 16 & Methanol & Positive \\
\hline 17 & Formate & Positive \\
\hline 18 & Succinate & Negative \\
\hline 19 & Lactate & Positive \\
\hline 20 & Pyruvate & Positive \\
\hline 21 & Salicylate & Positive \\
\hline 22 & Nutrient agar & Positive \\
\hline 23 & Fumarate & Positive \\
\hline 24 & Rhamnose & Negative \\
\hline 25 & Raffinose & Negative \\
\hline 26 & Esculine & Negative \\
\hline 27 & Cellobiose & Negative \\
\hline 28 & Melibiose & Negative \\
\hline 29 & Saccharose & Negative \\
\hline
\end{tabular}



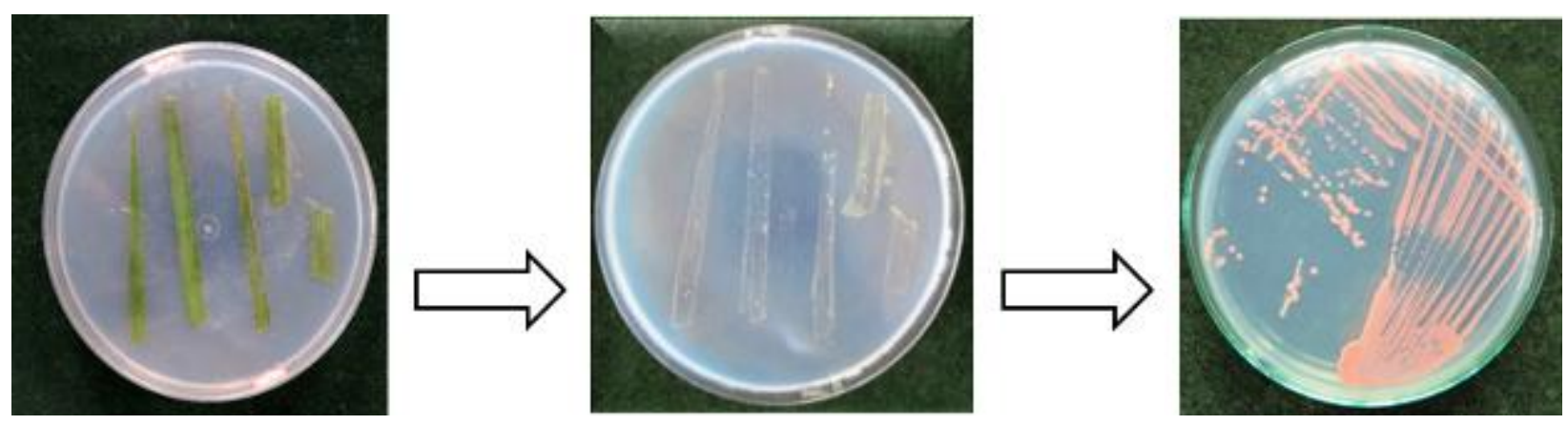

Plate 1(A). Isolation of Pink Pigmented Facultative Methylotrophs (PPFMs) by leaf impression method on AMS agar medium

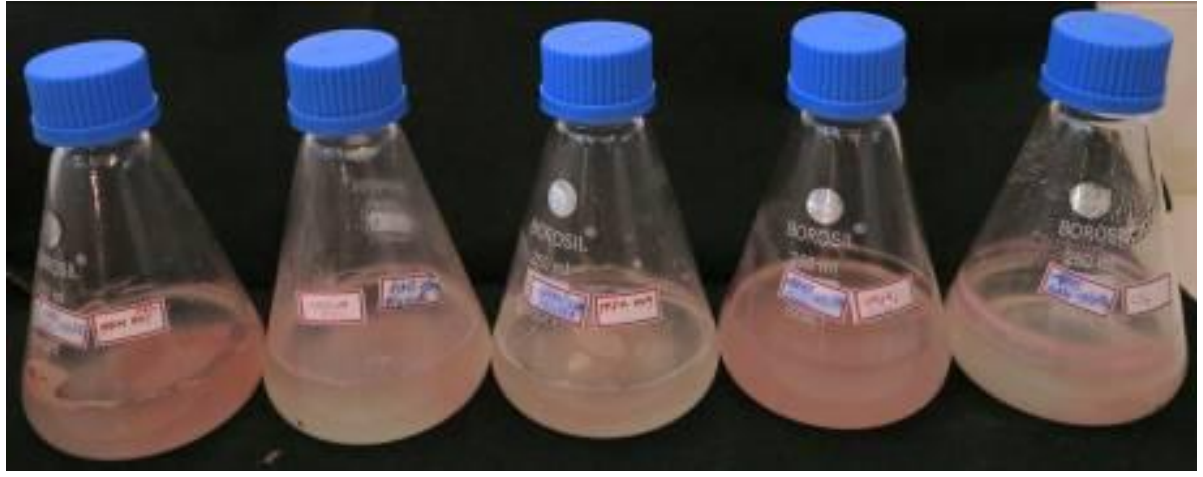

(B)

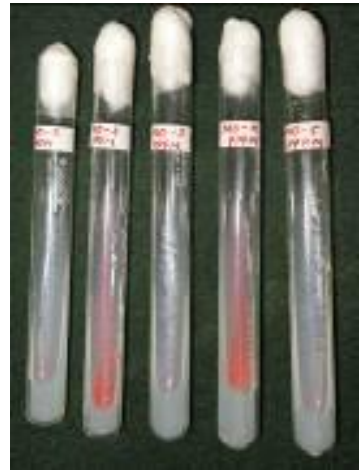

(C)

(B) Liquid culture of PPFM isolates

C) Maintenance of PPFM culture in slants 


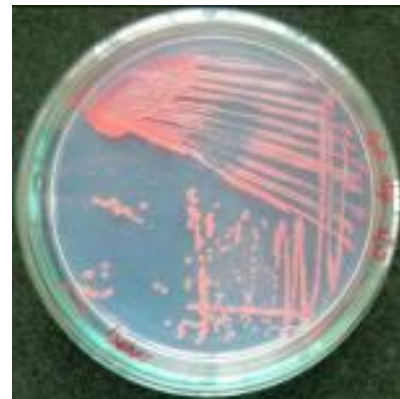

PPFM1

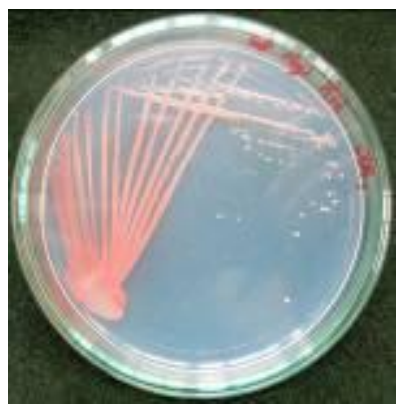

PPFM12

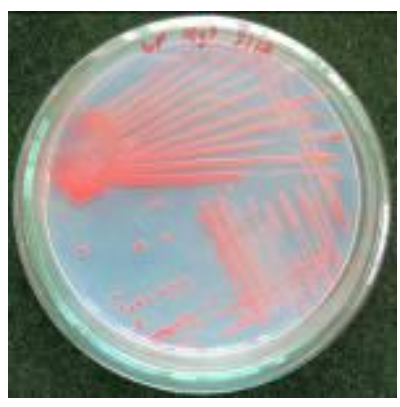

PPFM25

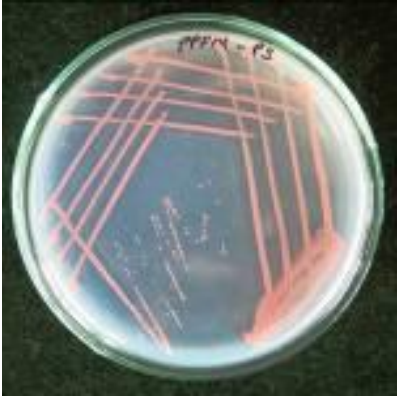

PPFM6

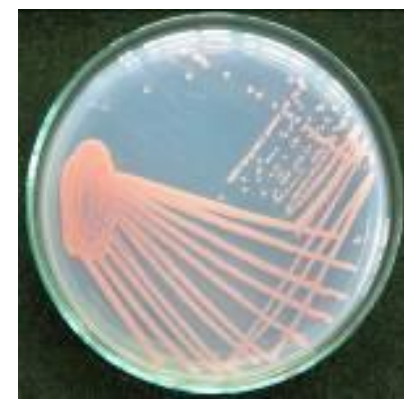

PPFM16

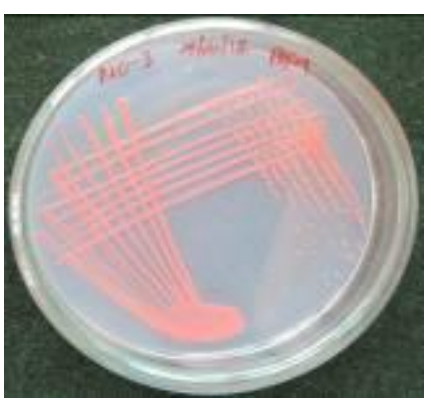

PPFM35

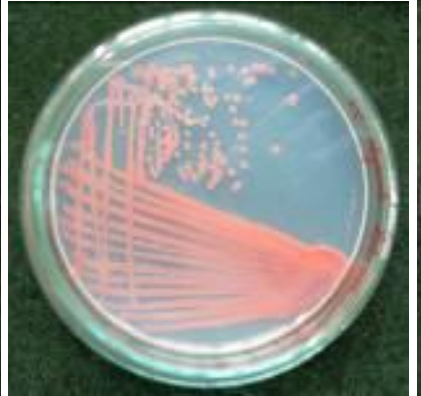

PPFM8

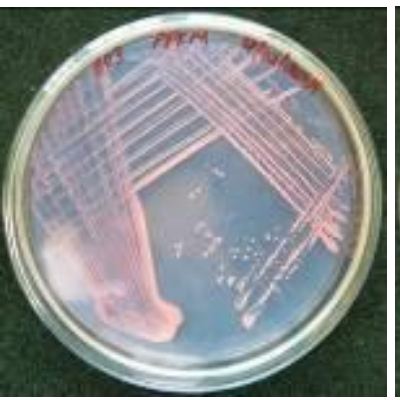

PPFM19

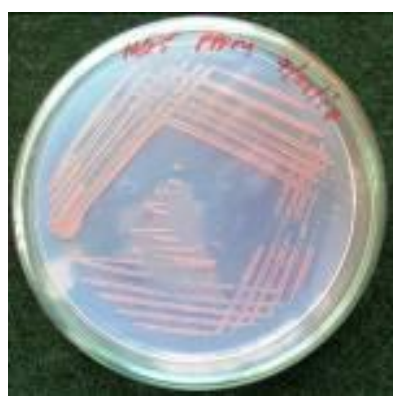

PPFM38

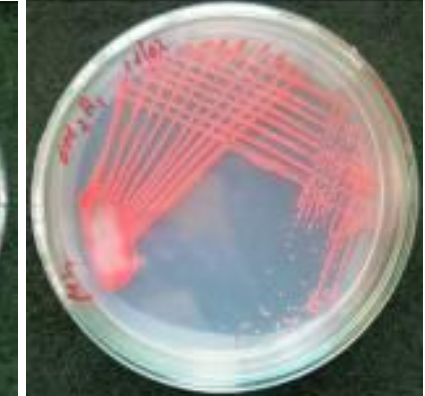

PPFM11

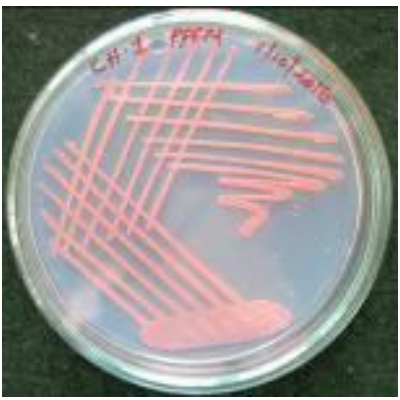

PPFM22

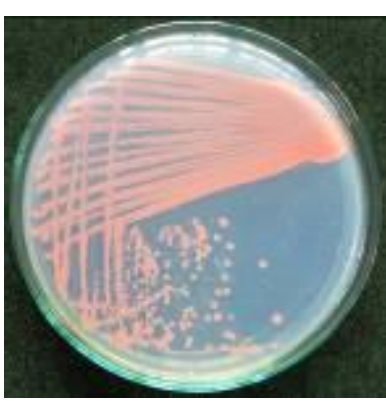

PPFM42

Plate.2 Different PPFM isolates obtained by leaf impression method 


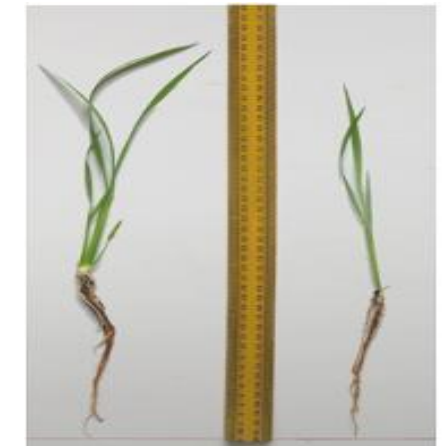

PPFM22

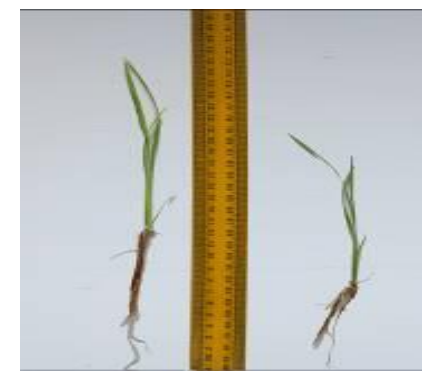

PPFM30

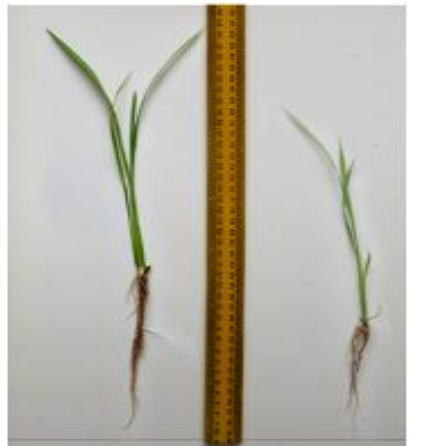

PPFM35

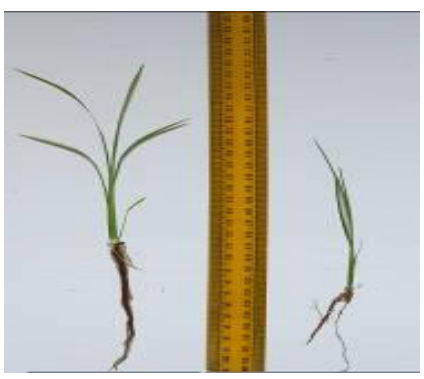

PPFM8

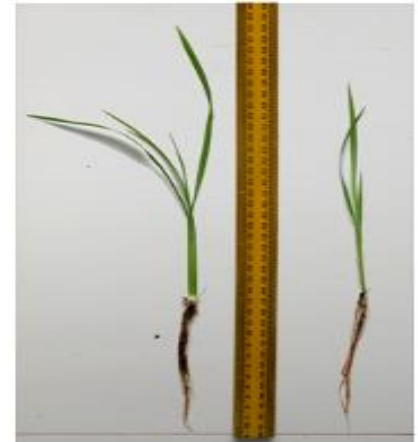

PPFM9 Control

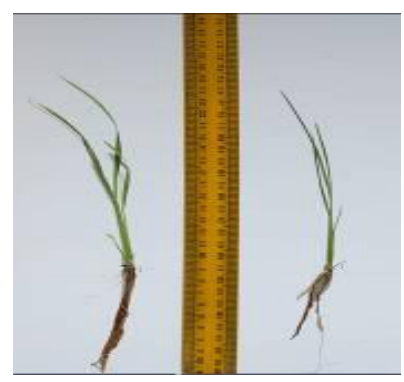

PPFM24 Control

Plate.3 Effect of PPFM isolates on shoot and root growth of paddy seedlings
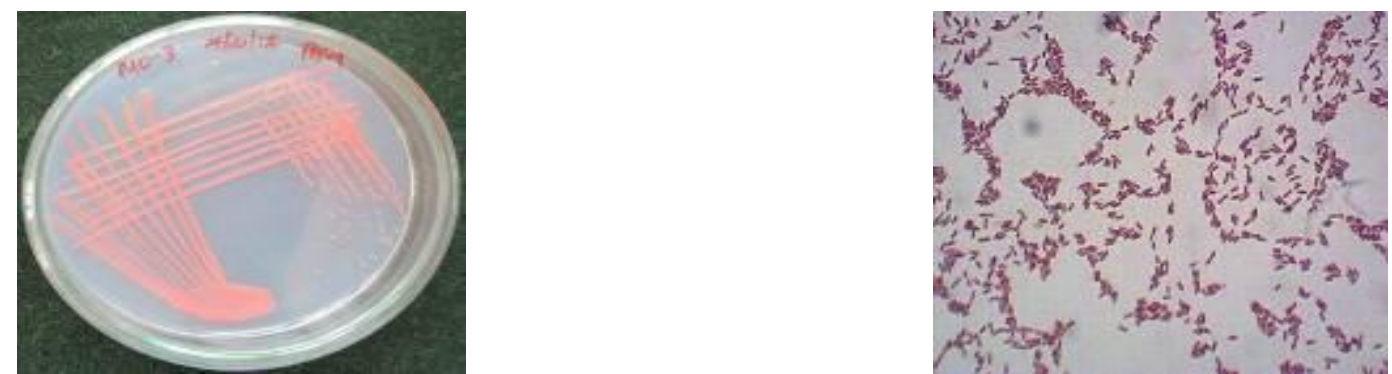

Plate.4 Colony morphology of the selected PPFM isolate and Gram reaction 


\section{Acknowledgements}

The authors are grateful to Kerala Agricultural University for providing research facilities.

\section{References}

Anitha, K. G. 2010. Enhancing seed germination of mono and dicotyledons through IAA production of PPFM. Trends Soil Sci. Plant Nutr. J. 1: 1418.

Baki, A. A. A. and Anderson, J. D. 1973. Vigour determination of soya beans by multiple criteria. Crop Sci. 143: 533537.

Basile, D. V., Basile, M. R., Li, Q. Y., and Corpe, W. A. 1985. Vitamin $\mathrm{B}_{12^{-}}$ stimulated growth and development of Jungermannia leiantha Grolle and Gymnocolea inflata Dum. Bryol. 88: 77-81.

Bellin, E. and Spain, J. C. 1976. The distribution of the isocitrate lyase serine pathway amongst one carbon utilizing organisms. Can. J. Microbiol. 22: 404-408.

Colby, J. and Zatman, L. J. 1973. Trimethylamine metabolism in obligate and facultative methylotrophs. Biochem. J. 132: 101112.

Corpe, W. A. 1985. A method for detecting Methylotrophic bacteria on solid surfaces. J. Microbiol. 3: 483-493.

Corpe, W. A. and Basile, D. V. 1982. Methanol- utilizing bacteria associated with green plants. Dev. Ind. Microbiol. 23: 483-493.

Gordon, S. A. and Weber, R.P. 1951. Colorimetric estimation of indoleacetic acid. Plant Physiol. 26: 192 195.

Fasim, F. N. 2003. Comparative study of air borne bacteria isolated from Karachi University. Pakistan J. Biol. Sci. 7: 664-647.

Green, P. N. and Bousifield, I. J., 1982. A taxonomic study of some Gramnegative facultatively methylotrophic bacteria. J. Gen. Microbiol. 128: 623625.

Holland, M. A. and Polacco, J. C. 1992. Urease-null and hydrogenase-null phenotypes of a phylloplane bacterium reveal altered nickel metabolism in two soybean mutants. Plant Physiol. 98: 942-948.

Ivanova, E. G., doronina, N. V., and trotsenko, Y. A. 2001. Aerobic methylobacteria are capable of synthesizing auxins. Mikrobiologiya. 70: 345- 347.

Jones, N. P. 2010. Molecular diversity of Arbuscular mycorrhizal fungi and pink pigmented facultative methylotrophic bacteria and their influence on grapevine (Vitis vinifera). Ph.D. (Ag) Thesis, University of Agricultural Science, Dharwad, 156p.

Jones N. P., Krishnaraj, P. U., Kulkarni, J. H., Pranav, C., Alagawadi, A. R., and Vasudev, A. R. 2007. Pink Pigmented Facultative Methylotrophs Solubilize Mineral Phosphates. Proceedings of $48^{\text {th }}$ Annual Conference, AMI, IIT, 1821 January 2007, Chennai, pp. 312314.

Jyothilaxmi., Palanichamy, V., Reddy, N., Rajsekaran, C., Kumari, N. V., and Bhaskar, M. 2012. Standardization of cultivation parameters for the extraction of carotenoid from pink pigmented facultative methylotrophic (PPFM) bacteria. Asian J. Pharma. Clin. Res. 5(2): 187-192.

Knief, C., Ramette, A., Franco, L., Blanco, A. C., and Vorholt, J. A. 2010. Site and plant species are important determinants of the Methylobacterium 
community composition in the plant phyllosphere. Int. Soc. Microbial Ecol. 4:719-728.

Lacava, P. T., Araujo, W. L., Marcon, J., Maccheroni, W., and Azevedo, J. L. 2004. Interaction between endophytic bacteria from citrus plants and the phytopathogenic bacteria Xylella fastidiosa, causal agent of citrusvariegated chlorosis. Lett. Appl. Microbiol. 39: 55-59.

Lee, H. S., Madhaiyan, M., Kim, C. W., Choi, S. J., Chung, K. Y. and Sa, T., 2006. Physiological enhancement of early growth of rice seedlings (Oryza sativa L.) by production of phytohormone of $\mathrm{N}_{2}$-fixing methylotrophic isolates. Biol. Fert. Soils. 42: 402-408.

Lidstrom, M. E. and Chistoserdova, L. 2002. Plants in the pink: cytokinin production by Methylobacterium. $J$. Bacteriol. 184: 1818.

Liu, Y. T., Sui, M. J., Ji, D. D., Wu, I. H., Cou, C. C., and Chen, C. C. 1993. Protection of ultraviolet irradiation by melanin of mosquitocidal activity in Bacillus thureingensis var. isralensis. J. Invertebrate Pathol. 62: 131-136.

Madhaiyan, M., Poonguzhali, S., Senthilkumar, M., Seshadri, S., Chung, H., Yang, J., Sundaram, S., and $\mathrm{Sa}, \mathrm{T} .2004$. Growth promotion and induction of systemic resistance in rice cultivar Co-47 (Oryza sativa L.) by Methylobacterium spp. Bot. Bull. Acad. Sin. 45:315-325.

Madhaiyan, M., Poonguzhali, S., Ryu, J., and Sa, T. 2006b. Regulation of ethylene levels in canola (Brassica campestris) by 1-aminocyclopropane-1carboxylate deaminase - containing Methylobacterium fujisawaense. Planta 224: 268-278.

Madhaiyan, M., Poonguzhali, S., Sundaram, S. P., and Tongmin S. A. 2005. A new insight into foliar applied methanol influencing phylloplane methylotrophic dynamics and growth promotion of cotton (Gossypium hirsutum L.) and sugarcane (Saccharum officinarum L.). Environ. Expt. Bot.57 : 168-176.

McDonald, R. C. and Fall, R. 1993. Detection of substantial emissions of methanol from plants to the atmosphere. Atmos. Environ. 27: 1709-1713.

Nemecek-marshall, M., MacDonald, R. C., Franzen, J. J., Wojciechowski, C. L., and Fall, R. 1995. Methanol emission from leaves: enzymatic detection of gas-phase methanol and relation of methanol fluxes to stomatal conductance and leaf development. Plant Physiol. 108: 1359-1368.

Omer, Z. S., Tombolini, R., Broberg, A., and Gerhardson, B. 2004. Indole-3-acetic acid production by pink-pigmented facultative methylotrophic acteria. Plant Growth Regul. 43: 93-96.

Radha, T. K. 2007. Studies on methylotrophs and their beneficial effects on soybean (Glycine max Merrill.). M. Sc. (Ag) thesis, University of Agricultural Science, Dharwad, 139p.

Raja, P., Uma, S., and Sundaram, S. 2006. Non-nodulating pink pigmented facultative Methylobacterium sp. with a functional nifH gene. World $J$. Microbiol. Biotechnol. 22: 13811384.

Reddy, S. B. V. 2002. Studies on PPFM as a new bioinoculant for groundnut. $M$. Sc. (Ag) thesis, Tamil Nadu Agricultural University, Coimbatore, 134p.

Senthilkumar, M. 2003. Evaluating diazotrophic diversity and endophytic colonization ability Azorhizobium caulinodans and Methylobacerium species in bacterised and biotized rice. Ph.D thesis, Tamil Nadu Agricultural University, Coimbatore, 78p. 
Simionato, A. V. C., Simo, C. C., Ifuentes, A., Lacava, P. T., Araujo, W. L., Azevedo, J. L., and Carrilho, E. 2006. Capillary electrophoresis-mass spectrometry of citrus endophytic bacteria siderophores. Electrophoresis 27: 2567-2574.

Thangamani, G. 2005. Studies on facultative methylotrophs for increasing crop production. Ph.D thesis, Tamil Nadu Agricultural University, Coimbatore, $284 p$.

Thangamani, G. and Sundaram, S. P. 2005. Potential of facultative methylotrophs in increasing the yield of tomato crop.
In: Proceedings of the ICAR National Symposium on Biotechnological Intervention for Improvement of Horticultural Crops: Issues and Strategies in Symbiohort, 10-12 January, 2005, Thrissur. Centre for Plant Biotechnology and Molecular Biology, College of Horticulture, Kerala Agricultural University, Thrissur, Kerala, pp. 362-365.

Whittenbury, R., Davies, S. L., and Wilkinson, J. F. 1970. Enrichment, isolation and some properties of methane-utilizing bacteria. J. Gen. Microbiol. 61: 205-218.

\section{How to cite this article:}

Nysanth, N.S., K.S. Meenakumari, Elizabeth K. Syriac and Subha, P. 2018. Isolation, Characterization and Evaluation of Pink Pigmented Facultative Methylotrophs (PPFMS) associated with Paddy Int.J.Curr.Microbiol.App.Sci. 7(07): 2187-2210.

doi: https://doi.org/10.20546/ijcmas.2018.707.258 